\title{
Between Negative Dialectics and Sexual Difference: Generative Conjunctures in the Thinking of Gillian Howie
}

\author{
Joanna Hodge
}

\section{Introduction}

Gillian Howie's first monograph, Deleuze and Spinoza: Aura of Expressionism (2002), is controversial and contestatory. ${ }^{1}$ She is unconvinced by recent materialist re-readings of Spinoza, and challenges the reading of Spinoza, inspired by Deleuze, as pursued variously by Rosi Braidotti and Moira Gatens, Paul Patton and John Protevi. ${ }^{2}$ Howie disagrees with those forms of feminist critique, which suppose that some combination of Spinozan, Nietzschean, or Deleuzian affirmations is a good route for feminist theorizing to follow today. Here is not the place to assess the detail of these disagreements, but they provide important points of reference for setting out the trajectory of her thinking. They also provide a context for the central intent of this chapter, which is to assess Howie's surprising proposal instead to combine an enthusiasm for Adorno's version of dialectics and for Irigaray's interrogations of gender as an alternative route into recasting the connection between philosophy, feminist critique and political engagement. Irigaray's interrogation of gender, in the form of a sexual difference, arrives in her claim: 'Sexual difference is one of the questions, if not the question which is to be thought in our epoch.' This claim arrives as the opening for her text, The Ethics of Sexual Difference, and it begs the questions: what is our epoch?

Gillian Howie, Deleuze and Spinoza: Aura of Expressionism, London: Palgrave Macmillan, 2002.

2 See Rosi Braidotti, Nomadic Theory: The Portable Rosi Braidotti, New York: Columbia University Press, 2012; Moira Gatens and Genevieve Lloyd, Collective Imaginings: Spinoza Past and Present, London and New York: Routledge, 1999; Paul Patton, Deleuze and the Political, London: Routledge, 1998; and John Protevi, Political Physics: Deleuze, Derrida and the Body Politics, London: Athlone, 2001. 
and what might the other questions be ${ }^{3}$ It makes a connection back to Martin Heidegger, for whom the question of thinking the defining issue for an epoch remains a signature theme.

The proposed conjunction of Irigaray, on sexual difference and Adorno on dialectics, would thus seem to come immediately into difficulties, granted the oppositional stance of Adorno towards Martin Heidegger and all his works, and the oppositional stance of the feminist movement, at least in Germany, to Adorno's mandarin masculinism. In this chapter, I propose to explore how these lines of conflict both provide Howie with a productive space for a wideranging thinking, and reveal the nature of Howie's ambitions for a contribution from philosophy, to contest how philosophy can engage with, and contribute to discussion of social and political process today. Howie's view is that the combination of Adorno's thoroughgoing challenge to Heidegger's fundamental ontology, with Irigaray's identification of sexual difference as the defining issue for this epoch, can provide a philosophical conceptuality more adequate for analysis of current conditions and the connection between philosophy and politics, than that proposed in the names of Deleuze and Spinoza.

Deleuzian neo-materialism has itself over the past twenty years been exposed to, and challenged by, Graham Harman's object-oriented ontologies, and by various versions of speculative realism, in the name of which yet another revival of political critique is surmised to be on the way. ${ }^{4}$ Howie develops her version of a connection between philosophy and political commitment in opposition to all these accounts. Her account draws rather on a critically inflected inheritance of the feminist and Marxist critiques of the 1980s, affirming a continuity with the projects of the Enlightenment, and of a universal emancipation, proposing a defence and elaboration of the ideals of reason and rights. In this context, theories of desire, associated with Freud and Lacan, have been conjoined to critiques of power in various combinations. These theories of desire have in turn been targeted by feminist critique, in general, in terms of a certain masculinist, or phallogocentric bias, and, more specifically, in terms of a Spinozan critique of the founding role in them of negation and disavowal, positing a primordial lack and experience of castration. Desire is thus to be emancipated from negation, and recast using components from the thinking of Marx, Foucault and Deleuze, in a general theory of energetics, forces and nerve systems. Howie resists such a line of argument, insisting with Adorno on a continuing

Luce Irigaray, An Ethics of Sexual Difference, trans. Carolyn Burke, London: Athlone, 1993, p. 5.

4 See Graham Harman, Tool Being: Heidegger and the Metaphysics of Objects, New York: Open Court, 2002; and Peter Gratton, Speculative Realism: Problems and Prospects, London: Bloomsbury, 2014. 
potential, and indeed necessity for thinking in terms of conceptions of negation and negativity, and affirming the powers of resistance contained within them. Critiques of power, associated with Marx and Engels, have also been put in question, both internally, with respect to Stalinist autocracy, and then externally, with respect to the failure of Soviet Communism. Louis Althusser, in his account of ideological state apparatuses, and Michel Foucault, on the enabling forces at work in power knowledge, provided analyses of the specific locations of discrete empowerments, ensuring some limited scope for effective interventions, and thus permitting a work of analysis to proceed, if always in opposition to powerful contravening forces. The development of a bio-politics of resistance in the writings of Antonio Negri and Michael Hardt do not come into Howie's overview, but she is sceptical about the limitations imposed on critique and on the power of negation, under the rubric of bio-politics. For Howie, the analyses of Althusser continue to show how academic philosophy provides one such relatively protected stance from which the task of critique is the less obstructed by forces above and beyond the control of individual citizens. While receptive to the claims of disaggregated emancipatory critique, in the names variously of the subaltern, the postcolonial and of disability studies, Howie remains committed to a strong version of philosophical universality, both with respect to rights and with respect to conceptual scope.

In the closing page of this first monograph, Deleuze and Spinoza: Aura of Expressionism, Howie briefly invokes Adorno's thinking as a resource for setting out an alternative route into materialism through a revival of his negative dialectics and of classical Marxist critique of ideology:

The task of criticising ideology, Adorno maintains, is to judge the subjective and the objective moments, and their dynamics. This returns to thought its three moments, the thought or judgement, the intentional object and the materiality of the object as well as returning to substance its content. ${ }^{5}$

This is no more than a gesture, and it is regrettable that extended treatment of Adorno's thinking, to demonstrate access to a materiality of its objects, remains lacking. In her second book, Between Feminism and Materialism: A Question of Method from 2010, Howie traces out how versions of feminist critique have sought to combine components from Freud and Marx, from Lacan and Althusser, and from Foucault and Barthes, to advance the cause of emancipation. In this context, the proposal to read Irigaray with Adorno, and

5 Howie, Deleuze and Spinoza, p. 205. 
Adorno with Irigaray, is perhaps the less startling. These various conjunctures of a post-Freudian theory of desire, and of post-Stalinist critiques of power, proffer accounts of subjectivity, as subjectivation, and subjectification; and of matter, as consisting in productive potentialities rather than as a set of positive givens. These latter are shown by Adorno, and, with his assistance, by Howie, as constantly at risk of reification into a naturalized potestas (power as possession), commodity fetishism, and a reification of economic process, in finance capital. Reification and subjectivation are the danger; genealogies of concepts and critiques of patriarchal power the cure. But, for Howie, these always remain subordinated to the imperatives of reason, and to analysis in terms of rationally grounded principles of identity, as pre-conditions for the very possibility for thought and critique. She thus inserts her analyses into the cumulative reception of these conjunctures, opening herself up to all the problems arising from the attempt to survey a truly vast range of material. ${ }^{6}$

Howie's two monographs, and the lines of enquiry subtended by them, thus arrive into a complicated, highly contested context, and they make a distinctive and unusual intervention. For while she insists on the claim of reason and argues for a priority of identity over difference, she is all the same focused on the processes whereby some are at ease, and some are set apart by current ways of thinking and of conceiving reason and identity. The title of her second monograph, Between Feminism and Materialism: A Question of Method,, itself makes clearer her angle of entry into this context of accumulating differentiations, between ways of reading Spinoza, and between ways of reworking a relation between philosophical and political commitments. The task in the second monograph is framed as that of pursuing the accounts of their lived experience offered variously by Kate Millett and Virginia Woolf. They, like Howie, are alert to concerns and experiences which fail to register within a dominant delimitation of the tasks of philosophy, even when a commitment to politics, as an awareness of the continuing work of extracting surplus value, is to the fore. The citation from Virginia Woolf's A Room of One's Own, placed at the head of the Acknowledgements to this second monograph, is instructive:

And I thought of all the women's novels that lie scattered, like small pock marked apples in the orchard, about the second-hand book shops of London.

\footnotetext{
There is some confirmation of her sense of a risk of losing something valuable in this work, in the current celebration of a new materialism, in the analysis offered in the Introduction to a recent collection New Materialisms. See Diana Coole and Samantha Frost (eds), New Materialisms: Ontology, Agency, and Politics, Durham, NC: Duke University Press, 2010.
} 
It was the flaw at the centre that had rotted them. She had altered her values in deference to the opinion of others. ${ }^{7}$

The longer citation runs:

One has only to skim those old forgotten novels and listen to the tone of voice in which they are written to divine that the writer was meeting criticism; she was saying this by way of aggression, or that by way of conciliation. She was admitting that she was 'only a woman', or protesting that she was 'as good as a man'. She met that criticism as her temperament dictated, with docility and diffidence, or with anger and emphasis. It does not matter which it was; she was thinking of something other than the thing itself. Down comes her book upon our heads. There was a flaw in the centre of it. And I thought of all the women's novels that lie scattered, like small pock-marked apples in an orchard, about the second-hand book shops of London. It was the flaw in the centre that had rotted them. She had altered her values in deference to the opinion of others.

Remarkable here is Woolf's easy command of the move from the 'I' of experience, and authorial activity, to the 'she' of the condition of the writer, condemned to obscurity by neglect and marginalization, to loss of confidence and failure of nerve. I am put in mind of all the volumes entitled 'Feminism and Philosophy' which similarly adorn the shelves of second-hand book shops, and fail to feature on lists of introductions to philosophy.

The charge made by feminists who are not philosophers is just that: feminist philosophers have altered their values in deference to the opinions of their male colleagues and become both compromised and silenced. The groups addressed by Howie are then feminists within philosophy, and feminists outwith philosophy; philosophers with feminist commitments, and philosophers without feminist commitments; and a whole range of writers on philosophy, politics and the logics of exclusion who may not wish to align themselves with either philosophy, or feminism, at all. For there are critiques of notions of being, and of becoming woman, of concepts of the subject and of identity, and of concepts of gender as non-binary, which appear to preclude commitments to feminist theory and critique. This is where Gayatri Spivak's concept of a strategic essentialism might come in: adopting a theoretical stance for the purposes of political solidarity, a limited conception of subject positions may thus be taken to provide a basis for forming alliances, and taking up forms of 
political activism. ${ }^{8}$ The range of reference in both of Howie's monographs is vast, and what follows must of necessity be selective and schematic in its account of her discussions. It is the fate of philosophical feminists to read both the women and the men, both inside and outside the discipline, whereas those with a less hospitable notion of the scope of the discipline have shorter reading lists. The following discussion falls into two sections: first, reading Adorno taking some instruction from Irigaray; and, second, reading Irigaray taking some instruction from Adorno, and they are designed to bring out the trajectory and distinctive tone of Howie's thinking.

\section{Reading Adorno with Irigaray}

As remarked, it is only towards the end of the first book, on Deleuze and Spinoza, that Howie introduces a suggestion, which remains important for her second monograph: an affirmation of Adorno's critique of ideological thinking. Objects of analysis adequate for giving an account of what there is are not available: the concepts are lacking, and these objects present themselves, if at all, only in distorted guise. This is the result both of the malign effects of historically dissociating contexts and, specifically, of processes associated with the commodity fetishism and a division of labour of late capitalism. Social relations appear as natural givens, and relations which should be thought as systems are taken as isolated parts, and subjected to cultural analysis rather than made part of a political critique. The forces and relations of late capitalist production restrict and distort processes of economic and cultural reproduction, imposing constraints on the stances and capacities available for those supposed to do the thinking. Thinking is obstructed and distorted by the noise and complicities generated in everyday transactions, and at best takes flight into relatively protected domains, shielded from the full force of a cultural appropriation. What appears valuable is made to appear so by interests concealed by the mechanics of a series of accommodations to what is.

Thus far, curiously, Adorno and his arch-enemy, Heidegger, find themselves in agreement. For Adorno, in his Minima Moralia: Reflections on a Damaged Life, ${ }^{9}$

8 In an interview 'Criticism, Feminism and the Institution' with Elizabeth Grosz from 1984, Spivak and Grosz rehearse the theoretical considerations which give rise to this notion of 'strategic essentialism', widely attribute to Spivak, but which Spivak herself has disputed. 'I think we have to choose again strategically, not universal discourse, but essentialist discourse' (p. 11), from Gayatri Chakravorty Spivak, The Post-Colonial Critic: Interviews, Strategies, Dialogues, ed. Sarah Harasym, London: Routledge, 1990.

9 See T. W. Adorno, Minima Moralia: Reflections on a Damaged Life, trans. E. F. N. Jephcott, London: New Left Books, 1974. 
regrets the passing of an overview from which what there is might be viewed in its entirety. Heidegger, by contrast, develops a critique of the total mobilization of cultural forces under Nazism, while remaining a supporter of the regime and the party until its demise in 1945. According to Heidegger's analysis, technology is not a question of technicity, politics is not a question of political forces: both must be relocated in terms of a far-reaching return to a founding philosophical question, why is there meaning rather than nothingness; and how has human inhabitation of the world resulted rather in a deepening nihilism rather than in a deepening sense for meaning and being (10 $^{10}$ Adorno has biting critiques of the abstract nature of Heidegger's language and concepts of history and technology in Jargon of Authenticity (1964) and Negative Dialectics (1966), but they share an analysis of a break in any supposed continuous history, with Adorno attempting to construct a connection back to a time before Nazism, and Heidegger vainly trying to peer into a future, after a completion of nihilism. They are marooned in a between time of history, for which Howie seeks remedy.

In the concluding pages of the Deleuze and Spinoza book, Howie writes of the constraints on thinking imposed by the material and social conditions of thought, as obstructing or at least delaying the formation, or stabilization of conditions for forming judgements about what there is; and for what there is to arrive in stable, identifiable form. ${ }^{11}$ When 'all that is solid melts into air', it is all the more difficult to establish an order of priorities and a logical sequence of thought. She continues the thought a few pages later, providing context for the previously given citation:

A break with idealism from the system of Hegel as well as Deleuze occurs when we pass to the object's preponderance and thereby to a material critique of the nature of the universal. The task of criticising ideology, Adorno maintains, is to judge the subjective and objective moments and their dynamics. This returns to thought its three moments, the thought or judgement, the intentional object and the materiality of the object, as well as returning to substance its content. ${ }^{12}$

The driving force here is, implicitly, the materiality of the object, or of the objectively given material conditions, however they may be socially manufactured, reproduced and re-enforced. The conception of substance is here inflected by the supposition that it acquires content by virtue of its modes of materialization,

10 This analysis begins in Being and Time (1927) and is continued in Of the Event: Contributions to Philosophy (1936-44), first published in 1989, and in the 'Letter on Humanism', written in 1946 and published in 1950, and the essay 'The Question of Technology' (1954).

11 Howie, Deleuze and Spinoza, p. 191.

12 Ibid., p. 205. 
which may be rendered incomplete, or partially obscured because of conflict with dominant accounts of the processes in question.

Theory is here construed as a practice conducted not by isolated individuals, but in groups of socially and culturally enabled people, whose modes of access to and ease of functioning within the forces and relations of cultural production are highly differentiated and charged up by inherited privileges and acquired disenfranchisements of all kinds. In this context, to acquire the status of a 'subject' is, like that of citizenship, a long and hazardous process consisting in a combination of good and bad luck, good and bad health, self-formation, and a sometimes distinctly uncomfortable set of conformisms and assimilations. The struggle to emerge out of these conditions is under interrogation in Adorno's most Nietzschean book, Minima Moralia. Not least among the lines of conflict between Adorno and Heidegger is a struggle for the inheritance of the thought of Nietzsche. Adorno emphasizes the elements of cultural critique and a multiplication of modes of Germanness (Luther and Hölderlin, Bismarck and Benjamin). For Heidegger, what comes to the fore are the analyses of the devaluation of all values in the decline, marked up by a supposed European tendency to nihilism. The effects of social uprooting and disenfranchisement, as experienced by Adorno, when moving first from Germany to England, and then to the US, are both under analysis and made plain to see in that notion of a damaged life.

There are two surprises in Howie's account. Deleuze and Deleuze's Spinoza are more usually understood to break with the various idealisms of their day, with Deleuze's transcendental empiricism proposed as a radical corrective to the idealistic versions of transcendentalism advanced in the names variously of Kant and of Husserl; and Spinoza is usually understood as the thinker of nature par excellence. For Howie, Deleuze is still locked into a mystificatory account of a univocity of being, affirming a metaphysical tradition which Howie reads as antipathetical to the production of a conceptuality adequate for an analysis of a current conjuncture. Deleuze himself does not of course endorse a materialism, rather preferring the term 'vitalism', but his writings have been deployed in support of a new thinking of matter, sometimes phrased as a commitment to a materiality without matter, and he certainly puts in question commitments to nineteenth-century notions of matter, as defined by permanence and continuity. Against this reading, Howie ingeniously argues that for both Spinoza and Deleuze, there is still a role for a creator, or divine originator which guarantees what otherwise may remain in doubt: the unity and thinkability of what there is. While Howie is committed to such a thought of unity and thinkability, hence 
the importance to her of a reading of Deleuze and of Spinoza, she supposes their arguments and demonstrations to be insufficient. Howie supposes that, for all his attention to new modes of materialization, for Deleuze, as for Spinoza, the univocity of being is a metaphysical commitment, not a materially demonstrable truth. Thus, Howie mobilizes a notion of materialism against Deleuze, and against that form of feminist critique, sometimes called the Australian tendency, which has adopted a Deleuzian version of a double affirmation, as a move to unite ethical and metaphysical imperatives: yes to life, and yes to a necessary role for that affirmation in putting life in some kind of order, such that it might be thought. For Howie, this is yet another version of the Munchhausen attempt to extract oneself from the swamp of indeterminacy by one's own pigtail, as critiqued by Nietzsche. ${ }^{13}$

In the second book, Between Feminism and Materialism, the implications of such an appeal to ideology critique and, more specifically, to the resources provided by Adorno's inquiries lead to a proposal to reinvent dialectical materialism. She states in the Acknowledgements, which is headed by the citation from Virginia Woolf, given above:

I also write to show that something politically relevant follows from the way we think about the relationship between subjects, objects, and their mediation. ${ }^{14}$

This of course is an echo of the remark in Virginia's Woolf's To the Lighthouse, in which philosophical research is described, I suggest satirically, in the following terms:

Whenever she 'thought of his work' she always saw clearly before her a large kitchen table. It was Andrew's doing. She asked him what his father's books were about. 'Subject and object and the nature of reality', Andrew had said, and when she said Heavens, she had no notion what that meant. 'Think of a kitchen table then', he told her, 'when you're not there.'

The alteration is significant with the plurals, subjects and objects, and the substitution of the notion of mediation for that of an objectively given 'nature

${ }_{13}$ The reference is to Nietzsche, Beyond Good and Evil: 'On the Prejudices of the Philosophers', Section 21 (trans. R. J. Hollingdale, Harmondsworth: Penguin, 1990, p. 51), where he analyses the dangers of deriving philosophical concepts from the terms and concepts made available by the mechanics of the day. It would of course be necessary to interrogate the use made by Nietzsche of the image at the start of that text: 'Supposing truth to be a woman - what? Is the suspicion not well founded that philosophers, when they have been dogmatists, have had little understanding of women'. The marvellous, but clearly false, implication of this remark is that women philosophers either do not understand women or are not dogmatists. Nietzsche's commitment is more likely existential: to the view that women are not philosophers, one which Howie, of course, sees it is necessary to dispute.

${ }_{14}$ Howie, Between Feminism and Materialism, p. xi. 
of reality. ${ }^{15}$ For Woolf's imagined philosopher, reality is one and indivisible, whereas for Woolf and Howie, Adorno and Marx, it is essentially contested. Howie writes, on the third page of her introduction:

If the problem before us is the relationship between 'the subject', however construed, and 'the object', however construed, then I suggest we should regroup around the idea of dialectical materialism. ${ }^{16}$

In that book she thus develops an account of a version of dialectical materialism, affirming a role for negation, and for a concept of negativity, which, for example, the analyses of Rosi Braidotti put into dispute in her critique of the version of them proposed and endlessly performed by Slavoj Žižek. The negation opposed by Braidotti, however, is not the negativity affirmed by Howie. For Howie, and indeed for Adorno, negativity provides a potency for disengaging from a dominant, disempowering discursivity, enabling the taking up of a stance elsewhere, in critical awareness of the limitations imposed by any domestication within an existing order. For Adorno, this negativity is to be thought in opposition both to conceptions of positivity, which for him have always been appropriated by the twin forces of the positivisms of nineteenthcentury science and liberal democracy, and to actually existing socialism, in which citizen spies on citizen, analyses proposed respectively by Karl Popper, and by the apologists for Stalin. ${ }^{17}$ These kinds of positivity, for both Adorno and Howie, form the greatest single barrier to critical emancipatory thinking and action, and, for them, any philosophy worthy of the name must start with a critique of them.

In a later section, in which she analyses concepts of identity, Howie adds some helpful footnotes on Adorno, and on this commitment to dialectics,

15 Howie is by implication sympathetic to the Nietzschean regret, as expressed in Twilight of the Idols Section 5: 'Reason', Philosophy (trans. R. J. Hollingdale, Harmondsworth: Penguin, 1968, p. 38): 'Nothing, in fact, has hitherto had a more direct power of persuasion than the error of being as it was formulated by, for example the Eleatics: for every word, every sentence we utter speaks in its favour! - Even the opponents of the Eleatics were still subject to the seductive influence of their concept of being: Democritus, among others, when he invented his atom. "Reason" in language: oh what a deceitful old woman! I fear we are not dispensing with God, while we still believe in grammar.' She would of course question why 'reason' is figured as an old woman, in a pejorative sense. There would, however, be room here for an affirmative reclamation. As Adorno remarks: 'No-one, who writes in German and who knows how much his thoughts are saturated with the German language, should forget Nietzsche's critique of this sphere.' In 'On the question "what is German?", from Stichworten, trans. Henry W. Pickford in Critical Models: Interventions and Catchwords, New York: Columbia University Press, 1998, p. 213.

16 Howie, Between Feminism and Materialism, p. 3.

17 For details of this in relation to sociology, see The Positivist Dispute in German Sociology with contributions from Adorno, Albert, Dahrendorf et al., ed. and trans. Glyn Adey and David Frisby, London: Heinemann, 1976). 
providing a clue to the trajectory of her thinking. She writes in one footnote of the relation back to the previous book on Deleuze and Spinoza:

Adorno continues by writing that positivity runs counter to thought and that it takes friendly persuasion by social authority to accustom thought to positivity.

This idea was the impetus behind my Deleuze and Spinoza book. ${ }^{18}$

This notion of 'friendly persuasion by social authority' has strong resonances with Gyorgy Lukács' notion of 'imposed reconciliation', and, for Howie, Lukács is another twentieth-century Marxist thinker important for her notion of developing philosophy as political critique. Relevant here are Lukacs' notions of reification, and his analyses of the amphibolies of attributing human agency to commodities, and to the technical relations through which they are produced, while rendering human beings inert functionaries within these processes. These concerns come to attention in this second book, in which Howie explicitly invokes History and Class Consciousness, and remarks on Juliet Mitchell's intervention, in 1971 in a proposal for a transformed Marxism, as follows,

That said, as early as 1971, Juliet Mitchell made an incontrovertible case against traditional Marxism: it would have to be a transformed Marxism. A workable account of women's oppression could not merely attach concepts of oppression to traditional Marxist theories. ${ }^{19}$

In another footnote, to the section on questions of identity, human and metaphysical, she marks a possible future development for a dialectical conceptuality, one which she takes up in her subsequent thinking of the disenablements, disempowerments and disenfranchisements specific to disabilities of various kinds, and attaching specifically to mortal illnesses. This conceptuality may provide resources for a preparation for death in life:

In this way dialectics could help to make sense of the self as a composite site and host for various life-forms or help find content for claims to intersectionality. ${ }^{20}$

She indicates how Adorno's thinking provides a selective version of a Nietzschean affirmation of life: and she is not going to allow life, and indeed the reading of Nietzsche, to be simply handed over to the vitalists and new materialists. ${ }^{21}$ Her

18 Howie, Between Feminism and Materialism, pp. 232-3, fn. 51.

19 Ibid., p. 28.

20 Ibid., p. 232, fn. 39.

${ }^{21}$ Here attention is due to Nietzsche's observation in Gay Science, Book III, Section 109: 'Let us beware saying that death is opposed to life: the living is merely a species of the dead, and a very rare species at that', which might be read as a critique of Hegelian dialectical construals of life and death. He goes 
discussion thus develops an account of concept formation informed by, but not continuous with, Adorno's analyses of how conceptions of a subject and an object are not as readily available as grammar might suggest.

Howie affirms a return to some version of a dialectical materialism within a certain history of philosophy, with a three-part account of materialism: reductionist, realist and dialectical. The first is shown to be hampered by a denial of the distinctiveness of conscious activity; and the second disenabled by the strangeness of what is to be encountered as states of affairs in the world. Dialectical materialism has for Howie the virtue of revealing how what there is in the world is in part produced by human activity, which is then denied by groups of human agents, seeking to evade responsibility for making it that way. Gaining access to what there is is part of the problem to be thought through, and Howie makes use of Hannah Arendt's distinctions between labour, work and action to mark up important differences between labouring within a given order, work to produce specific items within that given order and action to transform it. Howie writes:

First, drawing some inspiration from Arendt, we can designate three human activities: work, labor, an daction. ... To labor and to work, to produce independent objects for exchange, are historically and conceptually distinct and, although the distinction is masked, it reappears in Marx's categories of productive and unproductive labor. ${ }^{22}$

Thus, for example, primogeniture, patriarchy and Protestantism can be shown to be human artefacts, within a given order, confirmed in place by human action, not given as part of a natural order of things. However, they may be treated as the result of work and not of action, and thus responsibility for their maintenance and discriminatory effects may be denied.

In conclusion to her section on identity, she reveals that she is also proposing a reinvention of a radical feminism, revived by but not handed over to some of Irigaray's analyses. She invokes a triangulation of aims in theory informed by Marxist critique: a focus on the historical operations and processes of capitalist development; a deployment of a logic of contradiction to capture the conflictual and contestatory nature of relations in the world, as formed by capital; and a mode of political activism, designed to reveal and moderate the exploitative aspects of those two first features. She then remarks:

on to say: 'Let us beware thinking that the world eternally creates newness. There are no eternally enduring substances; matter is just such an error, like the God of the Eleatics.'

${ }^{22}$ Howie, Between Feminism and Materialism, p. 27. 
It has been my contention in this chapter that if we can see feminism as a similar triangulation, a reinvigorated notion of dialectical materialism will help us to grasp the dynamics of the historical processes of capitalism and this will, in turn, be informed by, and support a radical feminist politics. ${ }^{23}$

The grand surprise, then, is the way in which Howie thus supplements and subverts Adorno's known insensitivity to the claims of gender and race by this complex endorsement of a radical feminism informed by a reception of Marx and by Irigaray's disputes with Lacanian orthodoxy.

\section{Reading Irigaray with Adorno}

In Speculum of the Other Woman, Irigaray challenges the rewriting of psychoanalysis by Jacques Lacan, which deepens the subordination in Freud's thinking of female desire and identity formation to the requirements of a logic of male desire and identity formation. ${ }^{24}$ Irigaray appeals to a critique of a certain Engels in The Origin of the Family, of Private Property and the State (1884) of a naturalization of family relations in which human labour is laid open to exploitation. The implication is that Freudian and Lacanian theory serves to support the disenfranchisement of women with respect to these processes of appropriation. Those kinds of radical feminist critique which analysed the expropriation of value from women in the processes of human reproduction, and linked this to critiques of systems of enslavement worldwide, are not far away. Calling the child by the father's name and handing down property only to male heirs are merely the surface effects of a system of appropriation and control which finds its truth in the begetting of slave children on enslaved women, as enhancements of property rights. It is not just minerals and raw materials which are expropriated world-wide in the name of free trade, but populations sold into servitude and children born into slavery. These wider connections to a process of global exploitation, the middle class status of Freud's patients, and the relative privileges of those suffering from Lacanian and Žižekian angst, unfortunately drop out of view in Irigaray's subsequent work, but for Howie they remain to the forefront.

${ }^{23}$ Howie, Between Feminism and Materialism, p. 129.

${ }^{24}$ See Luce Irigaray, Speculum of the Other Woman, trans. Gillian C. Gill, Ithaca, NY: Cornell University Press, 1985. 
Howie reads in an important supplement to Irigaray's well-known observation, used as the title to a section of the pivotal insert in Irigaray's: Speculum:

Any theory of the subject is always appropriated to the masculine. ${ }^{25}$

The transposed version of Irigaray's claim focuses on the parallel Marxist claim: 'any theory of the object has always been appropriated to market value. Howie comments:

In the previous chapter we saw that the plane of feminist theory already includes models of complex and variegated social, political, and economic mechanisms that create hierarchies and asymmetries as well as the differential distributions of primary goods. With this in mind, I suggest starting with, and then departing from Irigaray's notion of the symbolic: a modified if not entirely new line of flight. ${ }^{26}$

It might here be necessary to modify this appropriation of the language of Deleuze and Guattari, and insert a series of plurals, lines of flight and planes of immanence, as construed in the name of a feminist thinking. Certainly, there are a number of planes in Irigaray's writings, but no direct contact to the Deleuzo-Guattarian notions of planes of immanence and lines of flight. In Speculum Irigaray opens her discussion, 'A blind spot in an old dream of symmetry', by citing Freud's famous observation concerning femininity in the New Introductory Lectures on Psychoanalysis,

The problem of femininity preoccupies you, if you are men. For the women, who find themselves among you, the question does not pose itself, since you are yourselves the enigma of which we talk. ${ }^{27}$

In Strachey's translation this is smoothed over, making less obvious the contrast between 'we men', who make up the group, talking amongst themselves, and 'you, the curious interloper'. ${ }^{28}$ Reading Woolf makes for a greater sensitivity to the importance of such apparently minor shifts of register. This figure works for Irigaray, in this study, as an emblem for the manner in which from Plato to Hegel, from Socrates to Lacan, and beyond, men have talked and, from time to time, women have been talked about, as partially present, arriving somehow on the edge of the matter in hand, for brief consideration and attention. Here, the

\footnotetext{
25 Irigaray, Speculum, p. 165.

${ }^{26}$ Howie, Between Feminism and Materialism, p. 58.

${ }_{27}$ Quoted in Irigaray, Speculum, p. 9.

28 Sigmund Freud, New Introductory Lectures on Psychoanalysis, Penguin Freud Library Vol. 2, trans. James Strachey, Harmondsworth: Penguin 1973, p. 146.
} 
power of a dominant hegemonic discourse posits the male as the norm, and the female as the exceptional aberrant case: in Hegel's words, the eternal irony of the tribe.

Summing up her discussion in that first section of her book of the blatant and more subtle expressions of sexism in Freudian theory, Irigaray draws on a Marxist account of value and of exploitation posing the well put question: 'what kind of economic infrastructure demands the conception of women provided by Freud?'29 She goes on to quote Friedrich Engels' observation from the Origin of the Family, of Private Property and of the State:

The first antagonism based on class which arrives in history coincides with the antagonism between men and women in monogamy and the first class oppression that of the female sex by the male sex.

Thus, Irigaray herself has motivated the thought that a critique of Freudian masculinism can go by way of an elaboration of Marxist theory. Her study of the derogation and exclusion of women in the history of philosophy, and in the practices of psychoanalysis, suggests how these practices replicate and reproduce the practices of an exclusion, transmitted through the two-thousand year history and practice of philosophy. These practices are, still in evidence in an inherited conceptuality, in which differential entitlements remain to this day a difficult topic to locate and address. The surface effect is the derogation of women and of femininity in psychoanalytical theory; the source of such derogation is the actual functioning of social and political relations of production and reproduction. Critique of these exclusions forms part of a more general critique of ideology, and it is thus something of a surprise, and indeed disappointment, when Irigaray subsequently renaturalizes a distinction between the female and the male, which Engels and Marx have thus put in focus as precisely historically produced in specific exploitative contexts, and as precisely not an organically, universally natural given. Thus any affirmation of Irigaray's insights requires a careful modulation through the questions posed to Eurocentric, and heterosexist, as well as to masculinist prejudice and distortion.

Howie thus works through her encounter with Irigaray, protected by her Marxist account of the various disenfranchisements of human beings, at various stages of their development, and the resulting exclusions from cultural production. Howie is sensitive to the radical feminist view that differences in relation to roles and tasks in reproduction are so great as to give credence

${ }^{29}$ Irigaray, Speculum, p. 150. 
to this notion, proposed by Irigaray, but not unquestioningly accepted by Howie, that sexual difference is the issue of our epoch. This claim arrives in the opening declaration of Irigaray's The Ethics of Sexual Difference, where Irigaray inserts her discussion of an exclusion of women and a repression of femininity within philosophy and psychoanalysis into her reception of Martin Heidegger's account of a series of epochs in the history of metaphysics. The inheritance from Adorno of rational critique, as critical immanentism, thus undergoes a startling transformation in Howie's hands, when she conjoins Adorno's critique to this reception of Irigaray's appropriation of the ontology of the arch-enemy, Heidegger, and of his thought concerning a word for being, which determines the fate of an epoch:

Each epoch, according to Heidegger, has one matter to think. Only one. Sexual difference is probably that of our time. The matter of our time which, once thought, will provide 'salut': rescue, health, welcome. ${ }^{30}$

The citation modifies Heidegger's claim, since the French 'salut' goes well beyond the ambiguity of Heidegger's own phrase, concerning the need for a rescue, Rettung, in a time of need.

Adorno identifies as key the duplicity of Heidegger's commitment to ontology, and to a conception of being, as empty signifier, permitting both persecutory and emancipatory investment. Adorno therefore declines to engage in such ontological speculation, preferring the registers of Kantian antinomy and of a Hegelian speculative proposition, left open-ended by a failure of the moment of its actualization in history. Howie, in her discussion of identity, thus invokes Adorno's arguments in Negative Dialectics (1966) to propose a rethinking of identity, in all its registers, through an affirmation of concepts of speculative identity, articulated as three distinct counterpoised registers of being, not as a single unified monolithic set of processes of approaching and withdrawal. In her discussion of 'Identity and Non-identity,' ${ }^{31}$ Howie emphasizes differences between the 'is' of formal identity (an apple is an apple); the 'is' of a judgement with ontological commitment (here is an apple); and the evaluative 'is': this is a health-giving apple. Matters get lively when this is transposed onto the social and historical sphere. The apparently tautological claim, 'a people is a people', should be contested, since the compositions of populations are historical accidents not historical necessities; the claim 'here is a people' must be approached with caution, since it is likely to have been appropriated by some

\footnotetext{
${ }^{30}$ Irigaray, Ethics of Sexual Difference, p. 13.

31 Howie, Between Feminism and Materialism, p. 115.
} 
self-absorbed leader, or racially motivated clique, seeking to promote their own cause, preservation, promotion or conatus. The next step is the politically lazy and dangerous claim: this people embodies a world historical destiny, to which other peoples must give way.

Adorno in his Jargon of Authenticity does not focus on the oddity of Heidegger's notion of history, which fails to address the specific conditions of historical processes in Germany in the 1930s and 1940s. Adorno there is intent on a more general critique of the insistence on ontology, and its claim to provide a critique of the inadequate commitments of everyday, taken-for-granted identities, while actually still holding on to them. For Heidegger, 'Germany' is some mythical entity, flowing from the mouth of the Danube in the Black Sea back into a heartland constituted by the Black Forest, through which a Roman inheritance is transformed back into an affirmation of autochthonous existing. The loss of foundations [Bodenlosigkeit] of metaphysical enquiry is to be restored by an affirmation of an ethnically specific grounding [Bodenständigkeit] in a locality. In Negative Dialectics, the inadequacies of Heidegger's account of history is in focus, drawing on the critique of Karl Löwith, and Heidegger's history can be shown to be not the critical history of Nietzschean invention, nor yet the antiquarian history in which Nietzsche allows for an insight into how the present differs from the past, and different pasts differ from each other. This is monumental history, claiming supremacy and exclusive access to both past and future, thus blocking all routes to growth, transformation, differentiation.

Howie thus follows Adorno's lead, but she does so under the guidance of Irigaray's insight that in this modern epoch what is to be thought are the differences between human beings, both within and between epochs. Irigaray's mobilization of the Heideggerian word for being may thus be informed, indeed enveloped by Irigaray's attention to a Spinozan counter-discourse, for a critique of the use of a concept of a neutral 'man' in accounts of undifferentiated human rights. In her discussion of Spinoza, Irigaray makes the following remark:

That 'man' wishes to be both man and woman is not news: the attempt always to return to an enveloping, to an interiority. But, in this willing to master everything, the master becomes the slave both of discourse and of a 'mother nature.32

Howie borrows from these movements of a return to Spinoza, and from Irigaray's immanent critique of a conception of a threatening 'mother-nature', while distancing herself from the restrictions consequent on both the Deleuzian and the

32 Irigaray, Ethics of Sexual Difference, p. 94. 
Irigarayan re-deployments of ontology. Howie proposes a retrieval of ontology, within the terms of the logic of suspicion, as inscribed by Adorno under the rubric 'the jargon of authenticity'; and this retrieval is inflected by her proposed modification of Irigaray's word for being in this new epoch. The word is still 'sexual difference', but now no longer focused on sexuate being, and a givenness of two mutually delimiting essences, but on a sexual difference, conceived as generative of differential, multiple, intersectional identities, in accordance with a Spinozan logic of multiple affective potentialities. These affective potentialities are to be accessed by affirming rather than seeking to transcend the positionality of thinking, as variously and transformatively embodied: between the various births and rebirths, and between imaginary, symbolic and actual deaths, to which human nature, as first and as second nature, is prone.

In her last five years, Howie was exposed with a new urgency to the imperatives of thematizing this, without traducing the impact of the various forms of physical infirmity, and of all the indignities of medicalization to which human beings are susceptible. This gave her a new appreciation for the work of Foucault on the Birth of the Clinic, and for Deleuze on the workings of principles of originary difference, and differentiation. The model for philosophical method remains one of subjective thought, material conditions, and the mediations provided by the concept, but there is here also in play a series of supplementations, whereby the masculinism of Adorno's thinking, however pessimistic and piecemeal, is moderated by the insistence on a radical feminism, and on the thinking of Irigaray, on the difference it makes to be female, and the experience of an exclusion which has its origin somewhere other than its immediately expressed forms . Thereby the implicit and not so implicit heteronormativity of Irigaray's views may also be moderated by inserting them into real-world contexts of lived differences, and the failures of abstract identifications to provide people with the means to access an understanding of their own conditions. It becomes possible to analyse how naively accepted or maliciously imposed notions of naturally given gender distinctions ensnare all human beings, but cut down with differential force and differential degrees of damage, with respect to empowerments and disempowerments, to gender dysmorphia and intersex conditions of all kinds. From medical interventions to impose gender distinctiveness on intersexed bodies, to cultural normalizations of who may claim to be respectively female or male, the politics of embodied differences have never been more pressing.

In her study, Luce Irigaray and the Philosophy of Sexual Difference, cited by Howie, Alison Stone puts the point with customary incisiveness: 
Intersexed bodies refute Irigaray's claims that all individuals are naturally either male or female: 'The whole human kind (genre humain) is composed of women and men and it is composed of nothing else. ${ }^{33}$

Following that up with:

The most compelling conclusion from intersex, then, is that it implies that there is no natural sex difference at all. This challenges Irigaray more radically, not merely affirming more natural sexes than she countenances, but holding her entire belief in natural duality to be misguided. ${ }^{34}$

Howie sets up a context for analysis in which Irigaray's dogmatism may be corrected by appeal to a speculative logic derived from Adorno; and Adorno's limited vision may be corrected by Irigaray's account of such blind spots, and by her attention to the silent force of an accumulating historical derogation of women. Irigaray's analyses may thus be exposed as succumbing to the temptation to take for natural what is only a feature of class interest, dividing up against each other the various sources of resistance to oligarchical appropriations of power and property. For Irigaray's gesture of naturalizing sexual difference, and rendering it a matter of 'to be two' reifies the very structure which she supposes herself to be putting in question. Instead of examining a mediatized and medicalized preoccupation with sexual difference, as a relation between two sexes, and then revealing such preoccupation as providing access to a disruption of such a mechanical, outdated conception, Irigaray oddly re-imposes a dogmatic account of an immobilized bipolarity. What Howie takes away from her encounter with Irigaray is a sensitivity to how - if, as a condition of entry into discussion, some irreducible aspect, necessary to one's own existence may have to be disavowed - there will be crucially disenabling effects on any capacity to participate effectively. The arrival of Adorno on the scene suggests that in some way or other all individual human beings are excluded by the criteria of entry into philosophical analysis, simply because the idealized subject addressed by regimes of meaning formation is simply that: idealized. At this point, the master who refused Irigaray her licence to practice, Jacques Lacan, also arrives on the scene, with his analysis of how the master's discourse is no discourse, for the master has nothing to prove, and it is only the one who aspires to mastery,

33 Alison Stone, Luce Irigaray and the Philosophy of Sexual Difference, Cambridge: Cambridge University Press, 2006, p. 114. Stone is quoting Luce Irigaray, I Love to You: Sketch for a Possible Felicity in History, trans. Alison Martin, London: Routledge, 1996, p. 84.

${ }^{34}$ Stone, Irigaray, p. 115. 
who engages in the contradictory task of trying to demonstrate mastery, which must always lie out of reach. ${ }^{35}$

\section{Conclusion}

In these two monographs, a hybrid theorization is in process, with a crossflow of enquiry and conceptuality between three significant if unlikely sets of resources, within which Howie's thinking is to be situated: the writings of Adorno, the thinking of sexual difference proposed by Luce Irigaray, and a politics of a minoritarian resistance, released from the constraining artifice of anti-Oedipalism, and from the restricting ontology of a body without organs, to which the Deleuzo-Guattarian reception is prone. For even anti-Oedipalism is still by derivation oedipal, and fails to reveal the full force of the exclusions, whereby those marked as other, and, amongst them, women can never enter into a symbolic order whether governed by Oedipal or by anti-Oedipal conceptual regimes. In contrast to a notion of 'Maxima Moralia', implying a universal status for moral maxims, Adorno adopts the phrase Minima Moralia, moral thinking in a minor key, recognizing the unavailability of universalizing, teleological fulfilments as charted by Kant and Marx, in terms of a categorical imperative and a worldwide revolution. When he encounters non-thematizable horror, he abandons macro-analysis in favour of micro-logical interrogations of cultural formations, constructed through prismatic refraction, in the modes of Eingriffe (1963) and Stichworten (1969), translated as 'Interventions' and 'Catchwords'. In her second book, Howie begins to adopt and adapt something like that serial, paratactic mode of construction of analysis and argument, whereby the whole may be intimated, even while it remains beyond the compass of an available conceptuality. She risks the unlikely conjunctures of Adorno's negative dialectics with radical feminism, of Irigaray's thinking with an emancipatory programme, affirming hybrid resources for a new conceptuality. For Adorno, and for Howie, philosophy continues in an afterlife scarred by its encounters with various totalizations, and totalitarianisms, and their attendant harms and destructions. Howie accepts the diagnosis of a drastically changed milieu for philosophizing, with rationality, as closed system, no longer a viable model of philosophical

\footnotetext{
35 See Jacques Lacan, 'The Production of the Four Discourses', The Other Side of Psychoanalysis, The Seminars of Jacques Lacan Book XVII (1969-70), trans. Russell Grigg, New York: Norton, 2007.
} 
practice; but she also affirms the non-negotiable inheritance of the ideals of rational enquiry.

\section{References}

Adey, Glyn and David Frisby (eds), The Positivist Dispute in German Sociology,

London: Heinemann, 1976.

Adorno,T.W. Minima Moralia: Reflections on a Damaged Life, translated by E. F. N. Jephcott, London: New Left Books, 1974.

Adorno, T. W. Critical Models: Interventions and Catchwords, translated by Henry W. Pickford, New York: Columbia University Press, 1998.

Braidotti, Rosie, Nomadic Theory: The Portable Rosi Braidotti, New York: Columbia University Press, 2012.

Coole, Diana and Samantha Frost (eds), New Materialisms: Ontology, Agency, and Politics, Durham, NC: Duke University Press, 2010.

Freud, Sigmund, New Introductory Lectures on Psychoanalysis, Penguin Freud Library Vol. 2, translated by James Strachey, Harmondsworth: Penguin 1973.

Gatens, Moira and Genevieve Lloyd, Collective Imaginings: Spinoza Past and Present, London and New York: Routledge, 1999.

Gratton, Peter, Speculative Realism: Problems and Prospects, London: Bloomsbury, 2014.

Harman, Graham, Tool Being: Heidegger and the Metaphysics of Objects, New York: Open Court, 2002.

Howie, Gillian, Deleuze and Spinoza: Aura of Expressionism, London: Palgrave Macmillan, 2002.

Howie, Gillian, Between Feminism and Materialism: A Question of Method, London:

Palgrave Macmillan, 2010.

Irigaray, Luce, Speculum of the Other Woman, translated by Gillian C. Gill, Ithaca, NY: Cornell University Press, 1985.

Irigaray, Luce, An Ethics of Sexual Difference, translated by Carolyn Burke, London:

Athlone, 1993.

Irigaray, Luce, I Love to You: Sketch for a Possible Felicity in History, translated by Alison Martin, London: Routledge, 1996.

Lacan, Jacques, The Other Side of Psychoanalysis, The Seminars of Jacques Lacan Book XVII (1969-1970), translated by Russell Grigg, New York: Norton, 2007.

Nietzsche, Friedrich, Twilight of the Idols, translated by R. J. Hollingdale,

Harmondsworth: Penguin, 1968.

Nietzsche, Friedrich, Beyond Good and Evil, translated by R. J. Hollingdale,

Harmondsworth: Penguin, 1990.

Patton, Paul, Deleuze and the Political, London: Routledge, 1998.

Protevi, John, Political Physics: Deleuze, Derrida and the Body Politics, London:

Athlone, 2001. 
Spivak, Gayatri Chakravorty, The Post-Colonial Critic: Interviews, Strategies, Dialogues, edited by Sarah Harasym, London: Routledge, 1990.

Stone, Alison, Luce Irigaray and the Philosophy of Sexual Difference, Cambridge: Cambridge University Press 2006. 